\title{
The Dysfunction of Criticism at the Present Time
}

JS: Here is an episode, a memory, from my first year as an Assistant Professor at the University of Wisconsin-Milwaukee. My colleague, Ihab Hassan, was giving a talk about contemporary theory, radical skepticism and the excesses of the hermeneutics of suspicion. Already weaning myself from that school of thought and thinking about a New Aestheticism, I was keen to hear his lecture. Hassan's office was next to mine, and I often chatted with the great man and "inventor" of Postmodernism. He seemed relieved that I wasn't another dreary postAlthusserian, neo-Marxist Foucauldian who, as Wordsworth put it, "murders to dissect" works of literature so that the helpless creatures will disclose their nefarious and deleterious ideological subtexts, etc., etc.

Hassan decorated his superb lecture with some of his favorite moments of poetry, if only to show, as he said, that "language can be good" (not a tissue of hateful lies subjugating some Subaltern or Other). During the question and answer period at the end, a feminist graduate student launched her hand and said, "I was insulted by how you brought out the dancing girls every so often." By this she referred to Hassan's favorite bits of poetry, his personal miscellany of lyric goodness that suggested his ideologically-suspect "love of literature." Dancing girls. I was appalled. In that assault on Hassan's good will towards literature, I first detected what I would like to call "the dysfunction of criticism at the present time." My echoing Matthew Arnold is, of course, canny. And I wonder what you make of the fact that for

How to cite this book chapter:

Begam, R. and Soderholm, J. 20I5. The Dysfunction of Criticism at the Present Time. In: Begam, R. and Soderholm, J. Platonic Occasions: Dialogues on Literature, Art and Culture. Pp. I 8-34. Stockholm: Stockholm University Press. DOI: http://dx.doi.org/Io.I6993/sup.baa.b. License: CC-BY-NC-ND. 
most of our professional lives, the following judgment of Arnold would be considered anathema:

But criticism, real criticism, is essentially the exercise of this very quality; it obeys an instinct prompting it to try to know the best that is known and thought in the world, irrespective of practice, politics, and everything of the kind; and to value knowledge and thought as they approach this best, without the intrusion of any other considerations whatever.

RB: The feminist deconstructionist and the Arnoldian humanist are the obverse and reverse of the same coin. She believes in the artlessness of truth, he in the truthfulness of art. Both are idealists seeking a language that escapes Nietzschean Allzumenschlichkeit and Rortyean contingency. She wants to get rid of the dancing girls, and he wants the "best" that is known and thought. But "best" for what? How we define exemplarity depends on context and function. There is no outside to the language game, no master discourse that transcends discourse. I would have responded to the graduate student with a simple question: "How can we know the dancing girl from the dance?"

More generally, I'm skeptical that all those literarytheoretical -isms ruined criticism. For me, the wind that blew out of the Continent in the I96os and into the musty halls of the Anglo-American academy had a mostly enlivening effect. So far from rendering criticism dysfunctional, the French and German schools-structuralism, post-structuralism, hermeneutics, reception theory, Marxism, etc.-gave new purpose and direction to the reading of literature. The problem was not Barthes, Foucault and Derrida, or Benjamin, Adorno and Iser, but a tedious and tendentious group of American academics who turned the dancing girls of the Continent into a parade of politically-freighted clichés.

JS: I take the "best" to refer to the value of being raised among beautiful exempla, including the best and most beautiful literature. To that extent I am a Platonist, I suppose, in believing that we have, as Lionel Trilling put it, a "moral obligation to be intelligent." I also have an obligation to preserve and uphold what I can loosely yet confidently call the content of a properly liberal arts 
education before that undertaking became nearly synonymous with a politicized, canon-busting "democratization" of literary studies. Let us forge ahead by being radical: rooted in a liberal imagination that enjoys the broadest possible set of connections between literature and culture without being a belligerent advocate for either a pristine formalism or a fatuous materialism. I am not plumping for a master discourse. I would make a case for English departments where one can observe a huge range of options for students, from the unashamed, vulgar Marxist to the unashamed, refined Formalist. They all have their version of dancing girls. But no one is rude or close-minded enough to call them that. Am I mistaken or has the latter creature nearly disappeared from the groves of Academe? And are we breeding students who really cannot tell the difference in quality between F. Scott Fitzgerald and James Joyce?

RB: You evoke Arnold and Plato and speak of the Beautiful, the True and the Good as though they were out for a joy-ride on a bicycle built-for-three. But these estimable qualities have little or nothing in common. Put them on a tandem and they will end up wrecked in a ditch or hedgerow. You of course know the concentration camp argument. Germany was one of the most highly educated and intellectually refined countries on earth in I940. Rubrgebiet factory workers listened to Furtwängler conduct Beethoven with rapt attention (I've seen the photos). And yet the program in the camps was murder by day and Mozart by night. All that beautiful Bildung did nothing to ensure right conduct. To the contrary, it produced one of the most catastrophic moral failures in human history. Returning to Hassan and the graduate student, we should remember that it is the grim feminist and the prim Victorian who strive to connect art and ethics. I share Kant's view that criticism, real criticism, only begins when we have drawn category distinctions that separate Reason, Morality and Beauty.

Having said that, I agree that literary studies in the academy have become dysfunctional, and one of the principal reasons for the current mess is ideologically-motivated reading. But I don't think we should "radically" forge ahead by returning to Trilling's idea of the "liberal imagination." What you propose is 
Trilling's update of Arnold with a dash of pluralism thrown in: the Deconstructionist Lion lies down with the Formalist Lamb. I would suggest something more radical: a return to a rigorously hermeneutic tradition in which the critic seeks to identify and calibrate Meaning and Significance-Sinn and Bedeutungaccording to such criteria as text, intention, production and reception. Jerome McGann has attempted this kind of highly layered and deeply textured reading with results that to my eye are extremely promising.

JS: I am not arguing for a literal or strict connection between art and ethics. I am suggesting that aesthetics-except in the rare case of the Nazis and a few other maniacs vended to us by history-always already dovetails with an ethical stance. Marxists and Feminists tend to ossify or literalize what is actually the most subtle and supple of sinews: that which makes many novelists (and their readers) incapable of cruelty and of being what Rorty calls "monsters of incuriosity." Proust could satirize his world but would not hurt a fly. Artists never murder. Beethoven was hard work as a man, but he never would or could kill anyone, and his Ninth Symphony has lifted millions more hearts than it has hardened or furnished with easy escapism. The aesthetic, properly conceived, quickens tenderness and curiosity. That's why even the acerbic Jane Austen is, finally, a gentle Jane, a forgiving ironist, a satirist and a shaper of kindred souls.

RB: William Burroughs shot and killed his wife during a drunken game of "William Tell." Norman Mailer stabbed his second wife with a penknife (how wonderfully symbolic!) and nearly did her in. Verlaine shot Rimbaud in a jealous rage and but for his bad aim there would be no Illuminations. Villon was in and out of jail his entire life and ended up murdering a certain Sermaise in a wine-sodden altercation. And Christopher Marlowe-a man who vied in reputation with Shakespeare-was killed after assaulting a companion over a drinking bill. One could of course expand upon this list, and if we include the number of writers who fought in wars-where no doubt the usual unspeakable atrocities were committed-the roll call of death and dishonor expands. Artists 
never murder? Gentle Janes all? I think not. Creative souls often mind neither their aesthetic nor moral manners.

JS: What can I say? I don't think your list of murdering artists can match up to the much longer list of artists who spent all their time trying to both gentle and complicate our souls by setting us off on what Verlaine called-rather beautifully-our "adventures among masterpieces." Your impressive handful of artist-thugs is just that. And not one writer on your list can hold a candle to Homer, Virgil, Dante, Shakespeare, Milton, Wordsworth, Tennyson, Hardy, Eliot, Joyce, Yeats and Beckett (I could go on and on). By the way, recent scholarship suggests that Marlowe ran afoul of Walsingham and his murder was actually a political assassination.

But let us swerve from artists and return to criticism for a few more dysfunctional moments. I don't think there are many Jerry McGanns left in the American academy. For every subtle and responsible critic (who can still write), I suspect there are three academic lemmings lining up to jump off the cliffs of their craggy hermeneutics of suspicion. Did you know, for example, that public school children in the U.K. are currently being fed the idea that Heathcliff represents the underclass or proletariat who returns to overthrow his oppressively-bourgeois masters? A Marxist reading of Wuthering Heights? Why not? If gentle Jane Austen can be tortured (most famously by Eve Sedgwick) into saying that her novels are about female masturbation (or its repression), then I suppose any dysfunction is possible.

RB: I was responding to your rather startling assertion that "artists never murder." My argument is that artists are a mixed lot—some good, some bad, some dreadful—and that there's no connection between the quality of their morals and the quality of their art. Ezra Pound, Louis-Ferdinand Céline and Wyndham Lewis were raving anti-Semites and enthusiastic supporters of Hitler and Mussolini. When Pound learned of the Nazi slaughter of Jews in Russia he responded with a line that scans beautifully: "Fresh meat on the Russian steppes." And yet Pound, Céline and Lewis are three of the greatest artists of the twentieth century. 
You say that "aesthetics always already dovetails with an ethical stance." I say where is the evidence?

As for criticism, it is indeed in a sorry state. But we have arrived at that state precisely because our reading of literature continues to be informed by a residual Arnoldianism. The Marxist and the Feminist both believe, along with Arnold, that art should morally instruct and improve. They simply disagree about what is instructive and what is improving. As I suggested earlier, hermeneutics offers an antidote to such moralizing by insisting on the distinction between Sinn and Bedeutung, a text's Meaning and a text's Significance. That distinction enables us to see that a great deal of current criticism falls into what philosophers call a "category error." Literary scholars often think that they're interpreting a text-attempting to understand its Meaning (what the author intended) - when in fact all they are doing is discussing its Significance for contemporary culture. Of course for the professoriate, contemporary culture means university culture, and university culture means a predictable set of political commitments.

JS: In stepping [over] slain meat, metrical feet create poetry, which is—as Pound says- "news that stays news." Poetry makes [the] new/s fresh flesh. Pound's line is not murder; neither is it murderously cruel. On the contrary, it intensifies-and prolongsthrough the trick of style the horror of the Nazi slaughter, not unlike how Homer's dactyls intensify the taste of spilt Trojan blood. That's my sensibility, at least.

As for the professoriate, I have not much to add to your own comments. They are debasing Arnold. If art does instruct and delight, then the sensitive, intelligent critic must attend to how it does those wonderful things. What nettles me most is the assumption that art is hawking ideological biases and making us more miserable once we discover the designs it has on us. Irvin Ehrenpreis once said that criticism should be $90 \%$ information, І $\%$ interpretation. Now we have г०\% interpretation and $90 \%$ cultural significance. Scholarship is mostly dead. And academics paradoxically increase their irrelevance the more they bray about their importance as "public intellectuals" who can teach nineteenyear olds how to read Pride and Prejudice as a vagina monologue. 
RB: But your own wonderfully perverse reading of Pound betrays the same kind of interpretive excess you condemn in the Marxists and Feminists. Given what we know of Pound's biography, it is clear that he was not registering his horror at the slaughter of Russian Jews, but celebrating what he saw as a fascist triumph. Why is it objectionable to transform Pride and Prejudice into a vagina monologue or Wuthering Heights into a Marxist revenge tragedy, but not objectionable to rewrite Pound's Jewhating remark?

So far you have avoided responding to my comments on the distinction between Meaning and Significance. Both E. D. Hirsch and Jerome McGann-in their very different ways-believe that authorial intention is something critics should attend to. What is your view? My sense is that you want to have your hermeneutic cake and eat it. You like frisky, risky readings when you do them. But you hate them in Terry Eagleton or Eve Sedgwick.

JS: My frisky readings are risky only in the sense that they are sometimes original. By “original” I mean nothing more or less than that they attend in precise ways to the origins of the work of art I) in its author's creative consciousness, 2) in its various cultural and historical contexts and 3 ) in my own evolving sensibility. This triad forms a kind of circuit within which my literary criticism sparks itself. I take on board your remark about my misreading of Pound's anti-Semitism. But, for me, the final effect of his "Fresh meat on the Russian steppes" is less to affirm or endorse the poet's baleful biases than to shine a torch on them in such a way that we can augur at once his hateful views and their stylization in poetic discourse. That Pound's unpleasant prejudices can be pleasantly scanned (in every sense) makes them important, memorable markers of the intersection of the lethal and the lyrical, the Unjust and le mot juste.

I don't like critics who are tactless in their friskiness. They grope the work of art in order to find what most obsesses them. The work of art becomes merely a platform or stage for the critic's hermeneutical floor-show of fantasy. One example of felonious friskiness should make my point.

I once heard a lecture by Susan McClary on Beethoven's Ninth Symphony. A feminist musicologist, she was on the verge of win- 
ning the coveted MacArthur Fellowship that nourishes promising geniuses. She argued in her lecture (subsequently published) that in Beethoven's Ninth the "point of recapitulation in the first movement of the Ninth is one of the most horrifying moments in music, as the carefully prepared cadenza is frustrated, damming up energy which finally explodes in the throttling murderous rage of a rapist incapable of attaining release." That sentence rightly provoked a huge debate called "Beethoven and the rape controversy." McClary considerably softened her tumescent reading in a later publication, but the mischief-and damage—had been done. I am hardly alone in seeing the excesses of McClary's "friskiness." Did she commit some sort of category error? At the very least, I would say that her "creative misreading" licentiously strayed from what one might call "tactful friskiness"-oxymoron cheerfully celebrated. But how much of criticism in the last forty years has been dominated by tactless, insensitive, overweeningly-suspicious habits of mind?

RB: Yes, the hermeneutics of suspicion has dominated much criticism of the last forty years and, yes, McClary's infamous Beethoven remark is an embarrassment. But I find many of her writings smart and incisive. I think Charles Rosen gives the most balanced account of her scholarship in "The New Musicology," where he observes that the impact of gender studies on musicology has been "uneven," producing work that ranges "from the enlightening to the loony." He commends McClary for her "racy, vigorous, and consistently entertaining style" and for her fine ear ("she hears what takes place musically with unusual sensitivity"), but he recognizes that her criticism often relies as much on showmanship as scholarship: "When she inflates her ideas, her purpose seems to be not so much to dazzle, or to attract attention, as to shock." At what point does shock become schlock and tactful friskiness "licentiously stray" into "overweening suspicion"?

As for your reading of Pound, Hans-Georg Gadamer would approve insofar as it fuses "originary" horizons-that is, insofar as it combines textual production, textual history and textual reception. In that sense, your approach is fully hermeneutic. But when you say the "final effect" of Pound's line is not to affirm 
the poet's biases but to expose them, the crucial phrase in your formulation is "for me." This is where one moves from Sinn to Bedeutung-from what the author intended to how it is "significant" for a particular reader. An anti-Semite apprehends "fresh meat" from one angle, a non-anti-Semite from another, and perspective may be determined as much by the author's meaning as by the reader's beliefs and desires. But-here things get complicated-there's another dimension at work here, which you have rightly insisted on. By visually and aurally heightening the image, Pound not only draws attention to what he describes, but also breaks down habitual patterns of perception. The effect is not to align morality with art, as Arnold would argue, but potentially to make available a new mode of seeing. And new modes of seeing may enable the reader to understand the world with a little more complexity, a little less reductiveness. Then again, as the example of the fabulously well-read Pound illustrates, it may not. In any event, it is in this area of indeterminacy that the relation of art to ethics becomes interesting.

One wonders if Plato and Aristotle, who wrote so influentially on this subject, are of any help here?

JS: Although Hermes was a Greek lad, I don't think the Greeks were all that hermeneutically sophisticated. For Plato, art and artists could remain in the polis if they were thoroughly ideal and idealizing. For Aristotle, the question is not whether art is good for the polis or its citizenry, but whether the work of art is harmoniously-and therefore powerfully-constructed; that is, if it is formally as "realized" as it can be. Even katharsis is subsidiary to that concern for-shall we say-the compelling "formality" of art. So if Plato would chuck out parts of Homer's Iliad where the hero is not acting like an ideal hero, Aristotle would sniff unpleasantly at a poorly-wrought tragedy if its plot were not, strictly speaking, in order. I'm not sure how those two ways of seeing art (the extrinsic and the intrinsic, the Platonic and the Aristotelian) graft onto our present discussion of Pound, Arnold, art, ethics and Beethoven, but perhaps they do if we could "only connect" them.

I do think "new modes of seeing" are precisely where the aesthetic kisses the moral. In one of his essays, George Steiner 
says, rather formally, that "whatever complicates consciousness is a high moral act." Beethoven's symphony does that, but McClary's work does not. In fact, her bellicose reductiveness is not only ridiculous: it is immoral. It is the horrifying aesthetic formality of "fresh meat on the Russian steppes" that makes the line at once so haunting, disgusting, beautiful and repellent. Only in news that stays news-because it is formally-stirring-can contradictory meanings and energies be held together in a way that makes us see (perceive, witness, comprehend, fathom, judge) more fully. Any critic who does not attend to-and take joy in-that miracle of dialectical tension should be banished from any Republic of Criticism. I admire truly literary criticism where the interplay between the work of art and the critic's hermeneutical friskiness is a peculiar form of intimacy where you may want to shoot the message and yet invite the messenger inside for a long evening of mutual dalliance. In the case of Hassan's miscellany of lyrical moments, his "dancing girls," one would be a fool to scare off that harem. It would be like killing a mockingbird.

RB: How we understand the function of criticism depends on how we understand the function of literature. Insofar as critics have considered literature socially significant, they have understandably worried about its moral effect. Plato and Aristotle provide two of the earliest accounts of that effect: the mimetic and therapeutic. It is well known that Plato regarded art as a poor imitation of ultimate reality, of the transcendent realm of the eidos. What is less well known is that Plato, like Oscar Wilde, also believed that reality-social and historical reality-imitates art. People are moved by an action in Homer, a character in Sophocles, a caress in Sappho, and they imitate what they have read, seen or heard. But since for Plato poets are more rhetoricians than philosophers, more interested in arousing emotions than promoting the Good, they are unreliable moral legislators and therefore dangerous to the body politic. Hence their banishment from the Republic.

Aristotle agrees that art has moral consequences, but he takes an approach radically different from Plato's. The affective dimension of art, the fact that it stimulates and manipulates the emotions, is for Aristotle not its weakness but its strength. Art 
functions like a good therapy session: it does not repress our darker impulses but isolates and exposes them, so that they may then be purged through katharsis. For Plato, seeing Oedipus sleep with his mother and kill his father promotes incest and patricide, but for Aristotle what happens in the Theatre of Dionysos stays in the Theatre of Dionysos. The audience is cleansed of its baser desires precisely by vicariously experiencing them.

Of course, both Plato and Aristotle are right. Young Weimarians dressed in blue jackets and yellow vests and put bullets through their heads in imitation of Werther. But plenty of other young Germans got all that Weltschmerz-not to mention Weltschmaltz - out of their system by reading Goethe's both wonderfully and ridiculously overwrought book.

So where does this leave us? I'm less convinced than you that "new modes of seeing" necessarily improve our ethical sensibility, and I reject Steiner's claim that "whatever complicates consciousness is a high moral act." But in a sense we are dancing aroundspeaking of dancing girls-the fundamental question of this dialogue, so I shall now ask it. Does literature-or, if you prefer, art-have a moral obligation? And if not, then what function does it serve?

JS: Only a tiny handful of Werther suicides are on the books and Goethe said he wrote the novel to "get it out of [his] system," so Aristotle mostly wins that battle. As for banishing the poets from his Utopia-well, it's a bit of a tangle. Plato's argument is fairly specific and, finally, perhaps deftly ironic, as some scholars have suggested in books with titles such as Plato's Defense of Poetry (Julius Elias). Nietzsche first suggested that line of defense when he claimed that in order properly to judge (and outmatch) the poets, Plato had to become a poet, almost despite himself. Hence, the literary and rhetorically-skillful dimensions to some of the dialogues, most notably Phaedrus and Symposium. Plato's Socrates discusses getting rid of parts of Homer's Iliad but certainly not the whole thing. He also discusses getting rid of certain pastries because they are too rich and fattening. One begins to suspect that Plato is not entirely serious about his astringent moral judgments regarding what gets thrown out of his Republic, that his stance might be shot 
through with ironic posturing. Plato's own use of myth (poiessis as myth-making), moreover, indicates that philosophy must sometimes rely on similes, allegories and other literary devices to make a bridge to those who resist straightforward didactic philosophizing. A dialectic is, after all—as we keep demonstrating - a fundamentally literary enterprise, a language game partly sustained by its rhetorical performances or, to speak metaphorically, its dancing girls.

As for art's "moral function," I think that oscillates happily between Plato's and Aristotle's insights about art that you adumbrated. Throw in Horace and Longinus. I don't really feel the need to take sides, but I do think that in superior works of art the extrinsic and the intrinsic approaches are both fully justified. If I had to choose, I probably would plump for Aristotle because I think that most art functions less to urge than to purge.

As for the critics, I wish only that they would approach literature with a little more respect for the ways in which it represents a triumph of Mind far superior to anything critics do. I am helplessly reminded of one of my favorite exchanges in Waiting for Godot when Vladimir and Estragon decide to while away the time by insulting each other. The triumphant insult says it all:

ESTRAGON: That's the idea, let's abuse each other.

They turn, move apart, turn again and face each other.

VLADIMIR: Moron!

ESTRAGON: Vermin!

VLADIMIR: Abortion!

ESTRAGON: Morpion!

VLADIMIR: Sewer-rat!

ESTRAGON: Curate!

VLADIMIR: Cretin!

ESTRAGON: (with finality). Crritic!

VLADIMIR: Oh!

He wilts, vanquished, and turns away.

RB: Yes, Plato is more complicated than his banishment of the poets from the Republic would suggest. Yes, not every teenage reader of Werther lodged a bullet in his head. And yes, critics are a dreary lot and should show more respect for the artists they criticize. But (again) we cannot address the function of criticism until we address the function of art. You want to split the difference 
between Platonic models of conduct and Aristotelian mechanisms of therapy. We might also throw in the Kantian approach, which involves what we have been calling "new modes of seeing" (Viktor Shklovsky's ostranenie or defamiliarization). All three of these approaches assume a social function, although Kant is careful to take the "moral" out of the equation.

Might we say that Plato, Aristotle and Kant treat art, especially literary art, as providing us with what Wittgenstein described as "forms of life"? "To imagine a language," Wittgenstein says in Philosophical Investigations "means to imagine a form of life," a way of being in the world, of making choices and acting upon them. Literature provides us with models of living, mechanisms of feeling, modes of perceiving, and these in turn guide and shape the decisions we make and the life we choose. It does not, however, assure that those decisions and choices will be moral any more than reading the Bible or the Nichomachean Ethics inspires one to help little old ladies across the street.

But if we agree that literature provides us with "forms of life," the question remains what is the function of criticism? Is it to explicate what authors intended when they imagined a particular form of life? Or is it something else, something more? And if so, where do we draw the line between what the critic half perceives and half creates?

JS: I take your point, at long last, about the dubiousness of saddling art with a moral mission. As Nabokov tirelessly reminds his readers, "Lolita has no moral in tow." My argument or claim all along is that great art somehow gentles our condition, Nazi concert-goers notwithstanding. On the whole, I think the "forms of life" you mention conduce to make people more interesting, entertaining, soulful, complicated, and possibly less damaging to others if their moral imaginations are quickened by reading stories about people who are brutal to others precisely because they do not use their imaginations. The most decorous example of that quickening could be the lesson Jane Austen's Emma learns at Box Hill when she insults Miss Bates, much to the dismay of the assembled picnickers, particularly Mr. Knightley, who sternly chastises Emma for her lack of feeling towards the poor, garrulous 
spinster. But to be alive to that lesson of charitable good mannerswhat Austen calls "those elegant decorums"-one must not be starving (Shaw: "Get your money first, then your morals") or crippled psychologically. I don't know if that quickening amounts to the "social function" of art.

I honor critics-Tony Tanner in the case of Austen-who seem to pay close attention to what's on the printed page at the same time they make startling connections textually, intertextually, culturally, biographically, etc., and yet without making the literary text into an allegory of a single, supervising theory. Great literature will always overwhelm any theory meant to explicate it. And sometimes the critic's biases really do pervert the text, as in the [in]famous case of Chinua Achebe's reading of Conrad's Heart of Darkness. So, I think the purpose of criticism is to illumine and partly join in the dance of seven veils, both showing how those veils are put on and how they may be peeled off, one by one, to help reveal more and more unfamiliar beauty. If finding/making so much beauty somehow makes us into less perfidious, cruel and selfish human beings, so much the better.

RB: "Quickening" puts the matter nicely. Literature is, as the ancients never tire of telling us, a form of instruction. It educates not only the mind but also the senses. We might call it, as Flaubert did, a form of "sentimental education." But-here I gather we now agree-that education cannot and should not guarantee moral rectitude.

Achebe's “An Image of Africa: Racism in Conrad's Heart of Darkness" provides a text-book example of the hermeneutic issue I have been stressing insofar as it blurs the distinction between what the author intended and how those intentions strike a contemporary. Achebe acknowledges Conrad's historical situation ("It was certainly not his fault that he lived his life at a time when the reputation of the black man was at a particularly low level”), but Achebe nevertheless pillories the Polish writer for depicting Africans as "savages," given the fact that the Congolese art of the period was highly sophisticated. Indeed the masks produced by the Fang people of the Congo region later inspired Picasso and Matisse to revolutionize modern art. But it is here that his- 
torical precision is important. Maurice Vlaminck first circulated the African masks among Western artists in I905. Conrad was in the Congo in I889. Roughly fifteen years mark the difference between one "image" of Africa and another, and that historical difference is crucial to any fair assessment of Conrad's novella. Achebe's essay commits three fundamental errors. It fails to separate the moral from the aesthetic; it fails to separate meaning from significance; and it fails to historicize. As a polemic the essay is engaged and engaging. As serious literary criticism it is mostly useless.

JS: Achebe fails to understand the complex meaning of Heart of Darkness and that's why he condemns it. Properly absorbed, Heart of Darkness is at once a stirring critique of Belgian rapacity and a contemporary document in racism. The novella also contains materials for a dozen, perfectly responsible interpretations, my favorite being Michael Levenson's superb essay, “The Value of Facts in Heart of Darkness." Unlike Achebe, Levenson responds to intention, text, context, history, philosophy, psychology and aesthetics in order to evolve a sensitive and complicated understanding of the way Conrad shows how value-laden "facts" really are, more so as we journey into the dark hearts of both Kurtz and colonialism.

To see the novella only as a racist text is to misread the text and its author's intentions. To me, art is the opposite of propaganda, and we are back to the question of Pound's anti-Semitism. Achebe wrongly imagines that Heart of Darkness is propaganda for European superiority and in doing so he ignores how well the novella scans as anti-European and as a story about the disintegration of a mind in the jungle-for starters. It is the task of the critic, as T. S. Eliot observed, "to be very, very intelligent." The responsible critic must, at the very least, strive for something resembling "disinterested contemplation" rather than allowing his or her interpretations to be tainted by disfiguring-and dysfunctional-biases (Beethoven's music is a rapist, Conrad is a racist, etc.). Just as art is not propaganda, so criticism is not obsession, nor theory mere fantasy. 
Piloting myself between the Scylla of Concrete Detail and the Charybdis of Abstruser Musings, I quickly tire of the "brilliancies of theorizing" unless the theories are truly brilliant. Even Stephen Dedalus, after "all in all," does not believe his own theory. Better to sacrifice a few speculations than to watch all one's works and days vanish in the devouring vortex.

RB: I think we have stumbled toward agreement. Literature is neither form nor content, neither the dancer nor the dance. It is both at once, acting in concert, and occurring in a specific time and place. Serious critics plot their course of explication along an array of vectors, including authorial intention, historical context, cultural situation, origins of production and horizons of reception. And they do all of this while remembering that literature is always an aesthetic as well as a semantic phenomenon-that it not only communicates meaning but also engages, indeed delights, the senses.

The crisis in literary studies at the university is not simply a matter of political correctness. It is also-I would say principally-a crisis in disciplinarity. Professional literary critics often have little idea of why they do what they do, beyond some vague sense of what will yield dividends in the scholarly marketplace. The result is the dysfunction of criticism at the present time.

As for theory, it has a significant role to play in revitalizing criticism, if only we had a theory worthy of the name. On my reading, Stephen Dedalus and James Joyce both believe in the efficacy of theory. Of course, Stephen plays many roles, one of which is Jesus, and he therefore speaks many languages, including the language of parable and allegory. His "theory" of Hamlet is really a theory of Ulysses, which is to say a theory of modernism. What he disowns is the literal application of the theory. Its allegorical application - the point where theory meets art-tells another story. But to understand that story, we must possess sufficient knowledge and skill to integrate the text that is Ulysses with the history that produced it and the theory that inevitably informs our reading of it. It is only then that the body will sway to music and the dancer will begin to dance. 
JS: And that's precisely when and where the detached, intelligent and intuitive reader of literature understands that Hassan's dancing girls are not merely decorative, far less ideologicallysuspect. They are forms of beauty-and forms of life-that unite our imaginations and judgment in such a way that we become capable of beautifully literary criticism. 